\title{
Morphological Study of the Liver in the Teleost Oreochromis niloticus
}

\author{
Estudio Morfológico del Hígado en el Teleósteo Oreochromis niloticus
}

Vicentini, C. A.; Franceschini-Vicentini, I. B.; Bombonato, M. T. S.; Bertolucci, B.; Lima, S. G. \& Santos, A. S.

VICENTINI, C. A.; FRANCESCHINI-VICENTINI, I. B.; BOMBONATO, M. T. S.; BERTOLUCCI, B.; LIMA, S. G. \& SANTOS, A. S. Morphological study of the liver in the teleost Orechromis niloticus. Int. J. Morphol., 23(3):211-216, 2005.

SUMMARY: Liver samples of Oreochromis niloticus cultivated in floating net cages were fixed for histological and ultrastructural studies with the objective of describing the hepatic parenchymal structure and the intrahepatic exocrine pancreatic tissue. Anatomically, the liver showed only two hepatic lobes. Histological analysis demonstrated that the hepatocytes were spread out as anastomotic cords, arranged in two cellular layers and surrounded by sinusoids. The intrahepatic exocrine pancreatic tissue exhibited an acinar arrangement and was diffused in the hepatic parenchyma. Structural analysis showed that the hepatocytes had a rounded nucleus and a rough endoplasmic reticulum with a parallel disposition to the nuclear membrane. The exocrine pancreatic cells showed secretion granules at the apical portion and the rough endoplasmic reticulum was concentrically distributed.

KEY WORDS: Liver; Exocrine pancreas; Morphology; Teleost.

\section{INTRODUCTION}

The liver of fishes is a dense organ ventrally located in the cranial region of the general cavity. Its size, shape, and volume are adapted to the space available between other visceral organs. In many teleostei species the liver is divided into three lobes. However, no lobulation was recognized in some teleostei (Bruslé \& Anadon, 1996). The hepatic parenchyma in fish is made of two cellular plates surrounded by sinusoids. Between two neighboring sinusoids, the hepatocytes are arranged as cords, generally two cells in thickness. The cords extended between central and portal zones (Hinton et al., 1972; Kendall \& Hawkins, 1975; Hinton \& Pool, 1976 and Bruslé \& Anadon).

Previous studies have indicated that in teleost fish, the pancreatic exocrine tissue develops around the portal vein during ontogenesis. It remains extrahepatic or penetrates somewhat deeply into the liver parenchyma depending on the species, as Ictalurus punctatus (Kendall \& Hawkin and Hinton \& Pool), Pimelodus maculatus (Marconi Stipp et al., 1980), Micropogon undulatus (Eurell \& Haensly, 1982), Serranus cabrilla (Gonzalez et al., 1993). Pancreatic tissue can be differentiated from hepatic tissue by its acinar arrangement. In addition, a thin septa of connective tissue separates the hepatocytes from the exocrine pancreatic cells (Bruslé \& Anadon).
Based on these data, the objective of the present study was to describe the morphological characteristics of the liver and the intrahepatic exocrine pancreas in Nile tilapia (Oreochromis niloticus). This species is of great interest to fish culture as it means fast growth, in addition to the fact that its meat is considered of excellent quality.

\section{MATERIAL AND METHOD}

This study used 30 samples of adult Nile tilapia, Oreochromis niloticus, cultivated in floating net cages that were placed in the Nova Avanhandava reservoir in Buritama, SP, Brazil. The fishes were anaesthetized with methaneasulfonate and the coeloma was opened for liver exposure, which was then removed for light microscopy and transmission electron microscopy studies. For light microscopy the liver samples were fixed in $10 \%$ buffered formalin and embedded in historesin (Leica, Germany). The histological sections were stained with haematoxylin-eosin and analyzed and documented photographically with an Olympus Bx50 microscope (Japan).

For transmission electron microscopy, liver fragments were fixed in glutaraldehyde 2,5\% in $0,1 \mathrm{M}$ phosphate buffer, 
$\mathrm{pH} 7.2$, for $3 \mathrm{~h}$, postfixed in $1 \%$ osmium tetroxide in phosphate buffer, washed in the same buffer, dehydrated in a growing acetone series and embedded in Araldite resin (Durcupan ACM, Fluka, Sigma-Aldrich , St. Louis , MO, USA). Resin polymerization was then completed in an oven at $60{ }^{\circ} \mathrm{C}$, for $48 \mathrm{~h}$. Ultrathin sections (60 and $80 \mathrm{~nm}$ ) were cut and transported to copper grids, contrasted with uranyl acetate and lead citrate, analyzed and documented photographically with a Philips CEM 100 transmission electron microscope (TEM), at the Electron Microscopy Center of the Institute of Biosciences of Botucatu, UNESP.

\section{RESULTS}

The liver of the Nile tilapia (Oreochromis niloticus) is a large organ and has only two lobes (Fig. 1). The left lobe is bigger and spreads throughout almost the entire corporeal cavity. At the visceral face it has the impression of the intestine. The gallbladder is well developed and has a rounded shape.

The hepatic parenchyma is made of hepatocytes spread out as anastomotic cords arranged in two cellular layers, and surrounded by sinusoids (Figs. 2 and 6). The bile ducts are usually found near the portal vein and they are lined by simple cuboidal epithelium. A concentric layer of collagen and muscular fibers were observed under the epithelium (Fig. 3).
Microscopic observations allowed the identification of the intrahepatic exocrine pancreatic tissue, as a result of its acinar arrangement and its diffused distribution in the hepatic parenchyma (Fig.4). The intrahepatic exocrine pancreatic tissue is separated from the hepatocyte cords by means of a thin septa of connective tissue.

Ultrastructurally, the hepatocytes show a single rounded nucleus, usually centrally located. The chromatin is granular, with more condensed heterochromantin located at the periphery of the nucleus. The nucleolus is more homogenous and presents high electronic density. The rough endoplasmic reticulum is often arranged in an array parallel to the nuclear membrane. The mitochondria are round to elongated and are associated to the rough endoplasmic reticulum. The different sized cytoplasmic vacuole were distributed throughout the cytoplasm (Fig. 5).

The exocrine pancreatic cells were ultrastructurally differentiated from the other cellular types by the presence of secretion granules, usually located at the apical portion of the cell. The nucleus of the pancreatic cells is generally round with a central nucleolus and it is located at the basal portion of the cell. The rough endoplasmic reticulum is well developed, revealing dilated cisternae concentrically distributed (Figs. 7 and 8).
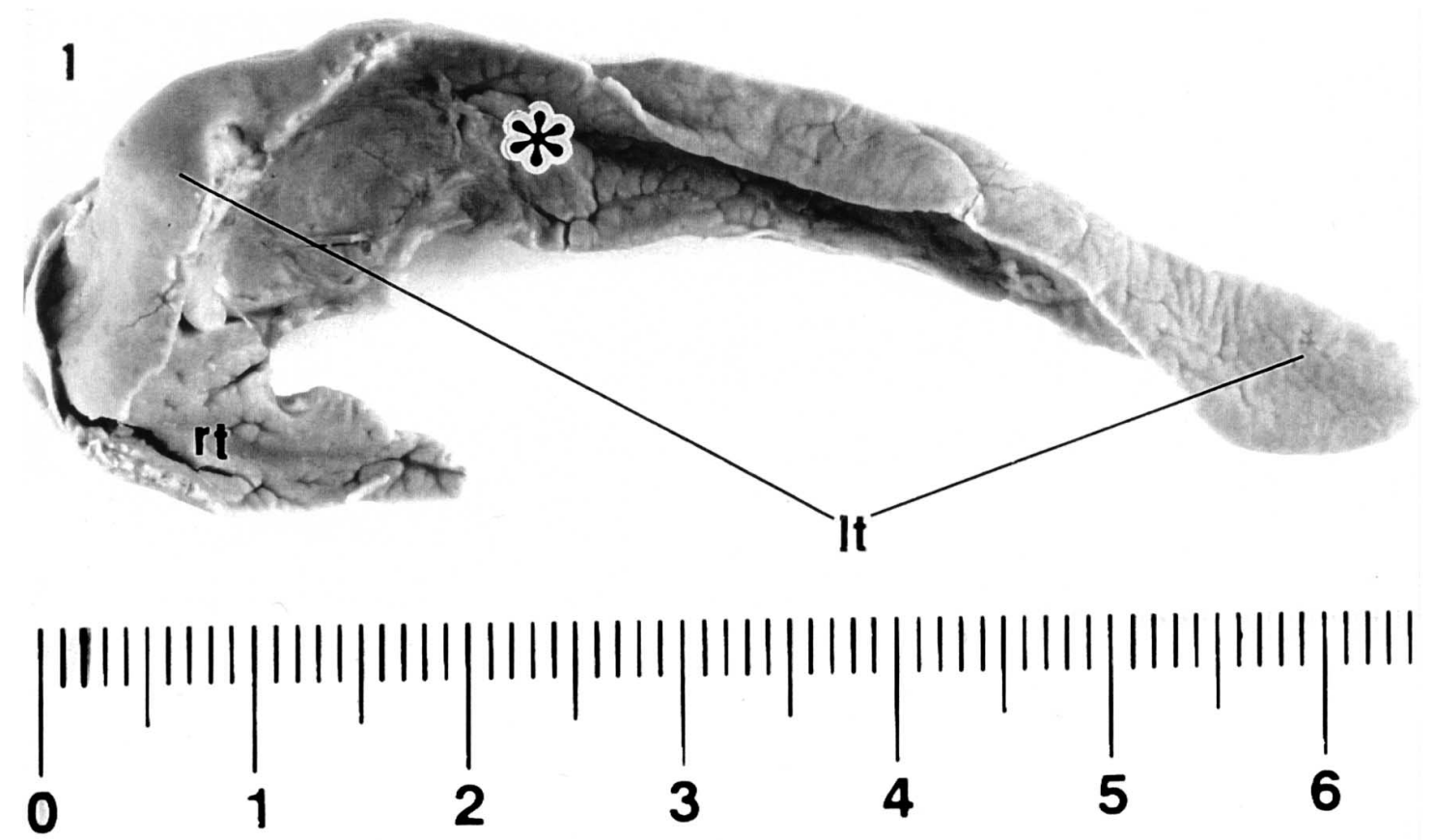

Fig. 1. Liver of Oreochromis niloticus showing two hepatic lobes: right (rt) and left (lt); and the impression of the intestine (asterisk). The gallbladder is removed. 

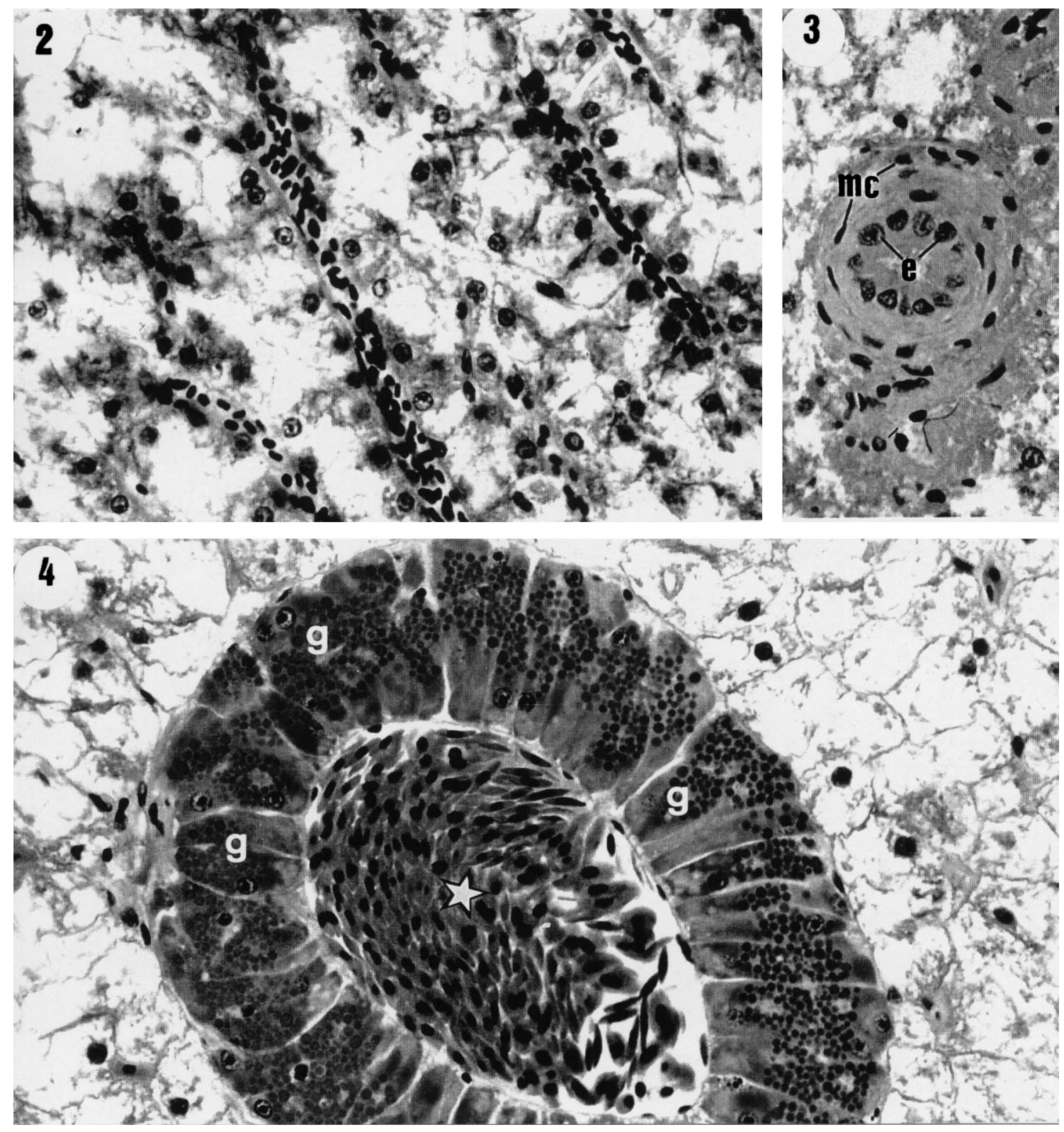

Fig. 2. Histology of hepatic parenchyma showing sinusoide arrangement, separated by hepatocyte cords, H/E x 400. Fig. 3. Bile duct showing simple cuboidal epithelium (e) and circular layer of muscular fibers (mc), H/E x 400.

Fig. 4. Organization of the intrahepatic exocrine pancreatic tissue around a blood vessel (star). Note the distribution of zymogen granules (g) in the exocrine cells, H/E x 400.

\section{DISCUSSION}

The histological structure of the liver of Oreochromis niloticus showed hepatocytes arrayed in cords, similar to what is found in many teleosts (Kendall \& Hawkins; Hinton \& Pool; González et al. and Bruslé \& Anadon). The absence of division into hepatic lobules and the lack of portal triads are features of Oreochromis niloticus, as evidenced in many teleosts (Hampton et al., 1985 and González et al.). However, some triads are found in Caranx spp. and Lutjanus bohar (González, 1992).

Observations achieved by optic microscopy also evidenced intrahepatic exocrine pancreatic tissue in 

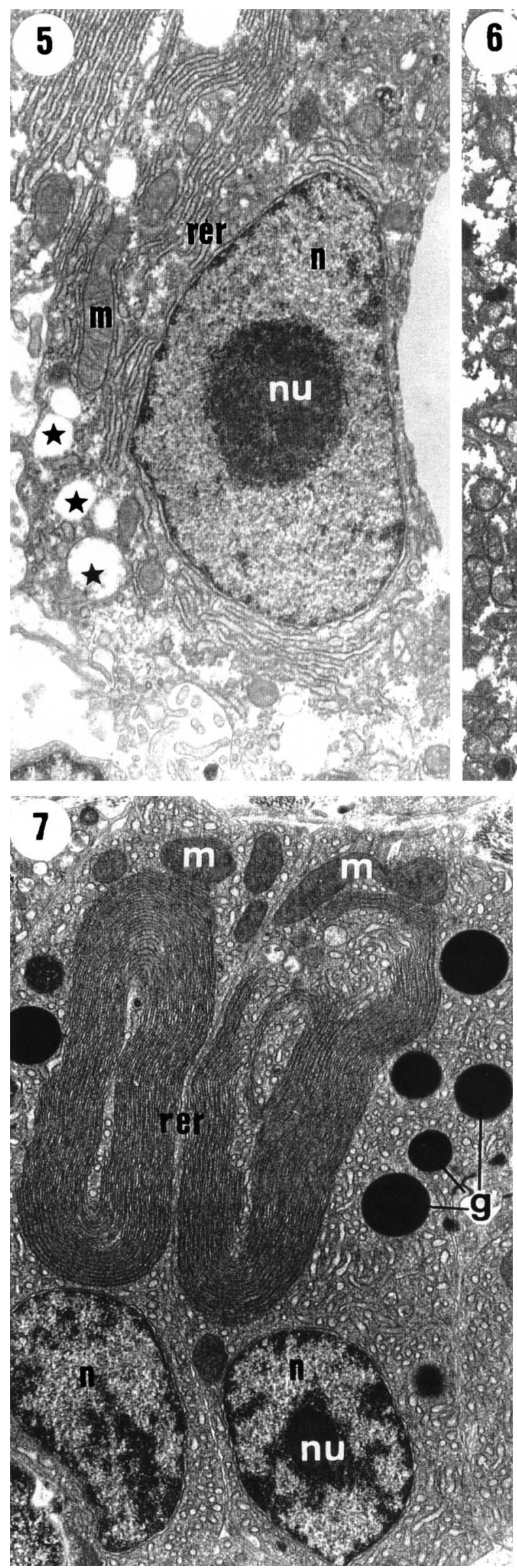
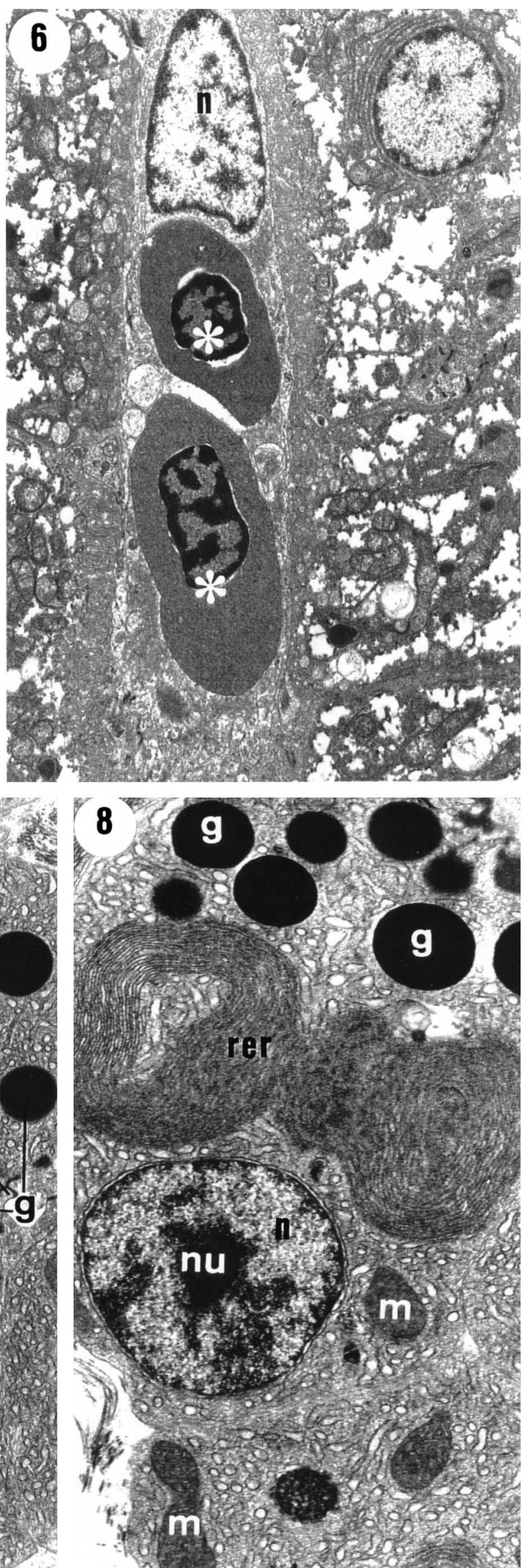

Fig. 5. Hepatocyte ultrastructure of Oreochromis niloticus. Nucleus (n), nucleolus (nu), rough endoplasmic reticulum (rer), mitochondria (m), vacuoles (stars), TEM x 9750.

Fig. 6. Electron micrograph of sinusoids: nucleated red blood cell (asterisks) and nucleus of endothelial cell (n), TEM x 4350.

Figs. 7 and 8 . E 1 e c t $r$ o $n$ micrograph of in trahe pat i c exocrine pancreatic cells. The distribution of zymogen granules (g) in the apical cytoplasm. Rough e nd o p las m i c reticulum (rer) revealing dilated cisternae concentrically distributed. Basal cytoplasm exhibiting nucleus (n), nucleolus (nu), mitochondria (m), TEM x 7750 and $x$ 9750 , respectively. 
Oreochromis niloticus, associated to afferent vases. Yet in some species, the pancreatic tissue was identified as diffused, surrounding the digestive tract (Beccaria et al., 1992 and Marconi Stipp et al.). The pancreas in Pimelodus maculatus is compact, enclosed by a thin layer of conjunctive tissue and is attached to the stomach and intestine wall as small masses of glandular tissue (Marconi Stipp et al.).

Ultrastructural characteristics of the liver of Oreochromis niloticus are in accordance with the observations attained by Kendall \& Hawkins; Hinton \& Pool and González et al. According to González et al. and Bruslé \& Anadon, the hepatocytes in fish are relatively poor in organelles, suggesting a low synthetic activity for secretory proteins.

In hepatocytes of various fish, a classical feature is the high content of glycogen, which fills most of the cytoplasm. However compared with those of mammals, fish hepatocytes do not metabolize much glycogen (Moon et al.; Hampton et al., 1985 and González et al.).

Exocrine pancreatic cells of Oreochromis niloticus exhibit similar characteristics to those of other teleosts (Kendall \& Hawkins; Hinton \& Pool; Marconi Stipp et al.; Beccaria et al.).

Sea bass (Beccaria et al.), subjected to long fasting showed the lumen of excretory ducts narrower and reduced cellular activity demonstrated by the scarcity of zymogen granules. On the other hand, intensively fed fish were seen to have increased cellular activity and greater quantity of zymogen granules. Electrodensed zymogen granules were abundant in Oreochromis niloticus. They were generally located in the apical portion of the cell. The rough endoplasmic reticulum was well developed and showed an organized pattern.

VICENTINI, C. A.; FRANCESCHINI-VICENTINI, I. B.; BOMBONATO, M. T. S.; BERTOLUCCI, B.; LIMA, S. G. \& SANTOS, A. S. Estudio morfológico del hígado en el teleósteo Oreochromis niloticus. Int. J. Morphol., 23(3):211-216, 2005.

RESUMEN: Con el objetivo de describir la estructura del parénquima hepático y del páncreas exocrino intrahepático del Oreochromis niloticus, fueron fijados para estudios histológicos y ultraestructurales fragmentos de hígado de peces cultivados en jaulas flotantes. Se evidenciaron sólo 2 lóbubos hepáticos. El análisis histológico demostró que los hepatocitos se encontraban organizados en forma de cordones anastomosados, dispuestos en dos capas celulares y cercados por sinusoides. El tejido pancreático exocrino intrahepático se encontró difuso en el parénquima hepático y se destacó por su organización acinar. El análisis ultraestructural demostró que los hepatocitos presentaban núcleos redondos y el retículo endoplasmático rugoso estaba dispuesto paralelamente a la membrana nuclear. Las células pancreáticas exocrinas presentaban gránulos de secreción localizados en la porción apical y el retículo endoplasmático rugoso estaba organizado de manera concéntrica.

PALABRAS CLAVE: Hígado; Páncreas exocrino; Morfología; Teleósteos.

\section{REFERENCES}

Beccaria,C.; Diaz, J. P. \& Connes, R. Effects of dietary conditions on the exocrine pancreas of the sea bass, Dicentrarchus labrax L. (Teleostei). Aquaculture, 101: 163-76, 1992.

Bruslé, J. \& Anadon, G. G. The Structure and Function of Fish Liver. In: Fish Morphology. Science Publishers, 1996. pp 77-93.

Eurell, J. A. \& Haensly, W. E. The histology and ultrastructure of the liver of Atlantic croacker Micropogon undulatus L. J. Fish Biol., 21:113-25, 1982.

González, G. Contribution à la connaissance des processus ciguatérigènes.Thèse de Doctorat (specialité Oceanologie), Université de Perpignan, pp 335, 1992.
González, G.; Crespo, S. \& Bruslé, J. Histo-cytological study of the liver of the cabrilla sea bass, Serranus cabrilla (Teleostei, Serranidae), an available model for marine fish experimental studies. J. Fish Biol., 43:363$73,1993$.

Hampton, J. A.; McCuskey, P. A.; McCuskey, R. S. \& Hinton, D. E. Functional units in rainbow trout (Salmo gairdneri) liver: arrangement and histochemical properties of hepatocytes. Anat. Rec., 213:166-75, 1985.

Hinton, D. E. \& Pool, C. R. Ultrastructure of the liver in channel catfish Ictalurus punctatus (Rafinesque). J. Fish Biol., 8:209-19, 1976.

Hinton, D. E.; Snipes, R. \& Kendall, M. W. Morphology 
VICENTINI, C. A.; FRANCESCHINI-VICENTINI, I. B.; BOMBONATO, M. T. S.; BERTOLUCCI, B.; LIMA, S. G. \& SANTOS, A. S.

and enzyme histochemistry in the liver of largemouth bass (Micropterus salmoides). J. Fish. Res. Bd. Can., 29: 531-4, 1972.

Kendall, M.W. \& Hawkins, W. E. Hepatic morphology and acid phosphatase localization in the channel catfish (Ictalurus punctatus). J. Fish. Res. Bd. Can., 32:145964, 1975.

Marconi Stipp, A. C.; Ferri, S. \& Sesso, A. Fine structural analysis of a teleost exocrine pancreas cellular components - A freeze-fracture and transmission electron microscopic study. Anat. Anz., 147:60-75, 1980.

Moon, T.W.; Walsh, P.J. \& Mommsen, T.P. Fish hepatocytes: a model metabolic system. Can. J. Fish Aquat. Sci., 42: 1772-82, 1985.
Correspondence to: Prof. Dr. Carlos Alberto Vicentini

Faculdade de Ciências de Bauru - UNESSP

Departamento de Cièncias Biologicas

Av. Luiz Edmundo Carrijo Coube s/n

CEP: $17.033-360$

Bauru-SP,

BRASIL

Email:carlosav@fc.unesp.br

Received: 13-04-2005

Accepted: 07-06-2005 